\title{
HBsAg quantification predicts off-treatment response to interferon in chronic hepatitis B patients: a retrospective study of 250
} cases

Shuai $\mathrm{Wu}^{\dagger}$, Wenfan $\mathrm{Luo}^{\dagger}$, Yin Wu, Hongjie Chen and Jie Peng*

\begin{abstract}
Background: For chronic hepatitis B (CHB) patients without willingness to extend the routine duration of interferon (IFN) therapy, it is important to identify patients who will benefit from treatment cessation. Hepatitis B surface antigen ( $\mathrm{HBsAg}$ ) quantification is recommended for management of IFN therapy. At present, the understanding on end-of-treatment (EOT) HBsAg level predicting post-treatment response to IFN is still finite.

Methods: A total of 2451 non-cirrhosis, HBsAg-postive patients treated with IFN-based therapy during the period from December 2010 to December 2017 at Nanfang Hospital were enrolled in this study. Serum HBsAg levels at EOT were measured to evaluate the associations between EOT HBsAg levels (Group 1, HBsAg $>0.05$ and $\leq 10$ IU/ mL; Group 2, HBsAg > 10 and $\leq 200 \mathrm{IU} / \mathrm{mL}$; Group 3, HBsAg > $200 \mathrm{IU} / \mathrm{mL}$ ) with post-treatment HBsAg loss. Chisquared, t-test,,Kaplan-Meier analysis, Cox regression analysis, and Multivariate Logistic regression analysis were used to analyse and evaluate differences between the there groups.

Results: The cumulative HBsAg loss rates 5 years after treatment in Group 1-3 were 30.4\% (17/56), 9.8\%(4/41) and $0 \%(0 / 153)(p<0.001)$. An EOT HBsAg level of $>10 \mathrm{IU} / \mathrm{mL}$ showed relatively high negative predictive value (NPV) of up to $97.9 \%$ for HBsAg loss. Low baseline HBsAg level $<25,000 \mathrm{lU} / \mathrm{mL}$, on-treatment $\mathrm{HBsAg}$ decline $>1 \mathrm{log} 10 \mathrm{lU} / \mathrm{mL}$ at week 24 and EOT HBsAg level $\leq 10 \mathrm{IU} / \mathrm{mL}$ were found significantly associated with HBsAg loss. A total of 6 patients have achieved HBsAg loss at EOT and 17 patients with EOT HBsAg level $\leq 10 \mathrm{IU} / \mathrm{mL}$ have achieved posttreatment HBsAg loss. Baseline characteristics, dynamic changes of on-treatment HBsAg and duration of IFN therapy were balanced across patients with EOT or post-treatment HBsAg loss.

Conclusion: EOT HBsAg level can serve as a monitoring indicator for IFN therapy. EOT HBsAg level $\leq 10 \mathrm{IU} / \mathrm{mL}$ was found to lead to high rate of post-treatment HBsAg loss. For patients without willingness to extend IFN treatment, off-treatment follow-up could be considered when HBsAg level decreased to $\leq 10 \mathrm{IU} / \mathrm{mL}$.
\end{abstract}

Keywords: Interferon, Chronic hepatitis B, End-of-treatment, Hepatitis B surface antigen, Post-treatment response

\footnotetext{
*Correspondence: pjie138@163.com

†Shuai Wu and Wenfan Luo contributed equally to this work.

Department of Infectious Diseases, Nanfang Hospital of Southern Medical

University, Guangzhou 510515, China
}

(c) The Author(s). 2020 Open Access This article is licensed under a Creative Commons Attribution 4.0 International License, which permits use, sharing, adaptation, distribution and reproduction in any medium or format, as long as you give appropriate credit to the original author(s) and the source, provide a link to the Creative Commons licence, and indicate if changes were made. The images or other third party material in this article are included in the article's Creative Commons licence, unless indicated otherwise in a credit line to the material. If material is not included in the article's Creative Commons licence and your intended use is not permitted by statutory regulation or exceeds the permitted use, you will need to obtain permission directly from the copyright holder. To view a copy of this licence, visit http://creativecommons.org/licenses/by/4.0/ The Creative Commons Public Domain Dedication waiver (http://creativecommons.org/publicdomain/zero/1.0/) applies to the data made available in this article, unless otherwise stated in a credit line to the data. 


\section{Background}

Within World Health Organization regions, hepatitis B virus (HBV) infection remains a major public problem with approximately 2 billion people infected globally. Among these, 240 million people have been suffering from chronic HBV infection, and nearly 650,000 individuals died annually of $\mathrm{HBV}$-induced liver failure, cirrhosis and hepatocellular carcinoma (HCC) [1-3].

To prevent disease progression, antiviral therapy is necessary. The main goal of therapy is to improve survival and quality of life by long-term suppression of viral replication, alleviating hepatic necroinflammation and fibrosis, and consequently reducing the risk of HCC development [4-8]. Recent guidelines recommend antiviral treatment with nucleos(t) ide analogues (NUCs) or with interferon- $\alpha$ (IFN- $\alpha$ ) for chronic hepatitis B (CHB) patients. The main efficacy of NUCs is to inhibit HBV replication leading to undetectable HBV DNA levels, but hepatitis surface antigen (HBsAg) loss, representing a functional cure, is rarely achieved. Moreover, due to the high risk of relapse after NUCs discontinuation, longterm consolidation treatment is often required, leading to increasing risk of drug-related side effects and drug resistance. Interferon (IFN) provides a finite duration treatment by direct antiviral effects and immune modulation, long-term immunological control after treatment discontinuation is also induced to impede viral activity $[9,10]$. It has been demonstrated by recent large randomised NEPTUNE study that the immune response of IFN therapy is durable for up to 5 years [11]. Since longterm benefits of CHB patients are held in highly regard, a five-year observational cohort study demonstrated that treatment with IFN leads to a significant lower incidence of unfavorable events than entecavir in $\mathrm{CHB}$ patients [12]. A phase 3 clinical trial has also reported that in hepatitis $\mathrm{B}$ e antigen (HBeAg)-positive $\mathrm{CHB}$ patients treated with IFN, 14\% initial non-responders achieved delayed response 6-12 months post-treatment, and 86\% initial responders maintained sustained response for up to 1 year [13].

Both Chinese and EASL guidelines recommend $\mathrm{HBsAg}$ quantification for management of IFN therapy [14, 15]. For $\mathrm{HBeAg}$ positive patients with $\mathrm{HBsAg}$ level $<200 \mathrm{IU} /$ $\mathrm{mL}$ or $\mathrm{HBeAg}$ negative patients with $\mathrm{HBsAg}$ level $\leq 10$ $\mathrm{IU} / \mathrm{mL}$ at the end of IFN therapy, extended treatment is recommended [14]. However, for individuals, whether extended treatment will lead to HBsAg loss and how long the treatment will last, remain unknown. Thus, for $\mathrm{CHB}$ patients without willingness to extend IFN therapy, it is important to identify patients who will benefit from treatment cessation. Recent researches identified baseline HBsAg quantification and on-treatment dynamic changes of HBsAg as predictors for treatment response to IFN [16-21]. However, the understanding on HBsAg level predicting post-treatment response to IFN is still finite [22].

We thus conducted a retrospective study using the data of CHB patients treated with IFN-based therapy at Nanfang hospital (Guangzhou, China). The main aims of this study were (1) to investigate the association between end-of-treatment (EOT) HBsAg level and posttreatment HBsAg loss, (2) to identify factors associated with EOT HBsAg level or post-treatment HBsAg loss.

\section{Methods \\ Study population}

This was a retrospective study consisting of consecutive CHB patients who have received IFN-based therapy (standard IFN-alpha or peg-IFN alpha) during the period from December 2010 to December 2017 at Nanfang Hospital of Southern Medical University in Guangzhou, China. This hospital is a public-care, teaching-medical centre in Guangzhou that serves as a patient referral centre and accepts patient referrals from every part of Guangzhou. A total of $2451 \mathrm{HBsAg}$-positive patients were enrolled in this study. All patients had the same inclusion criteria: HBeAg-positive, over 18 years old, with IFNbased therapies only or combined with oral nucleos $(t)$ ide analogues for at least 3 months, without hepatitis $C$ virus or other viruses co-infection, without cirrhosis and with intact follow-up data at baseline, EOT and after cessation of treatment. The details of the follow-up were shown in Fig. 1. All patients were divided into three groups in accordance with EOT HBsAg levels: Group 1- HBsAg > 0.05 and $\leq 10 \mathrm{IU} / \mathrm{mL}(n=56)$, Group $2-\mathrm{HBsAg}>10$ and $\leq 200$ $\mathrm{IU} / \mathrm{mL}(n=41)$, Group 3- HBsAg $>200 \mathrm{IU} / \mathrm{mL}(n=153)$. The EOT HBsAg cut-off value selection was based on previous studies $[22,23] . \mathrm{HBsAg}$ loss was defined as serum $\mathrm{HBsAg}<0.05 \mathrm{IU} / \mathrm{mL}$.

\section{Data collection}

Data were collected by reviewing the medical records of each patient. The records included demographic characteristics (age and sex), HBsAg levels, HBV DNA viral load, duration of IFN, laboratory values (ALT).

\section{Laboratory testing}

Serum HBV DNA was tested with a polymerase chain reaction HBV assay with a lower limit of detection (LLOD) of 1000 copies/mL (Daan Gene Co, Ltd.; Sun Yat-sen University; Guangzhou, China). Serum HBsAg was quantified using the ARCHITECT HBsAg assay (range $0.05-250 \mathrm{IU} / \mathrm{mL}$; Abbott Laboratories, Chicago, Il, USA).

\section{Statistical analysis}

Continuous variables were shown as mean \pm standard deviation (SD) and median (min-max) for data with 


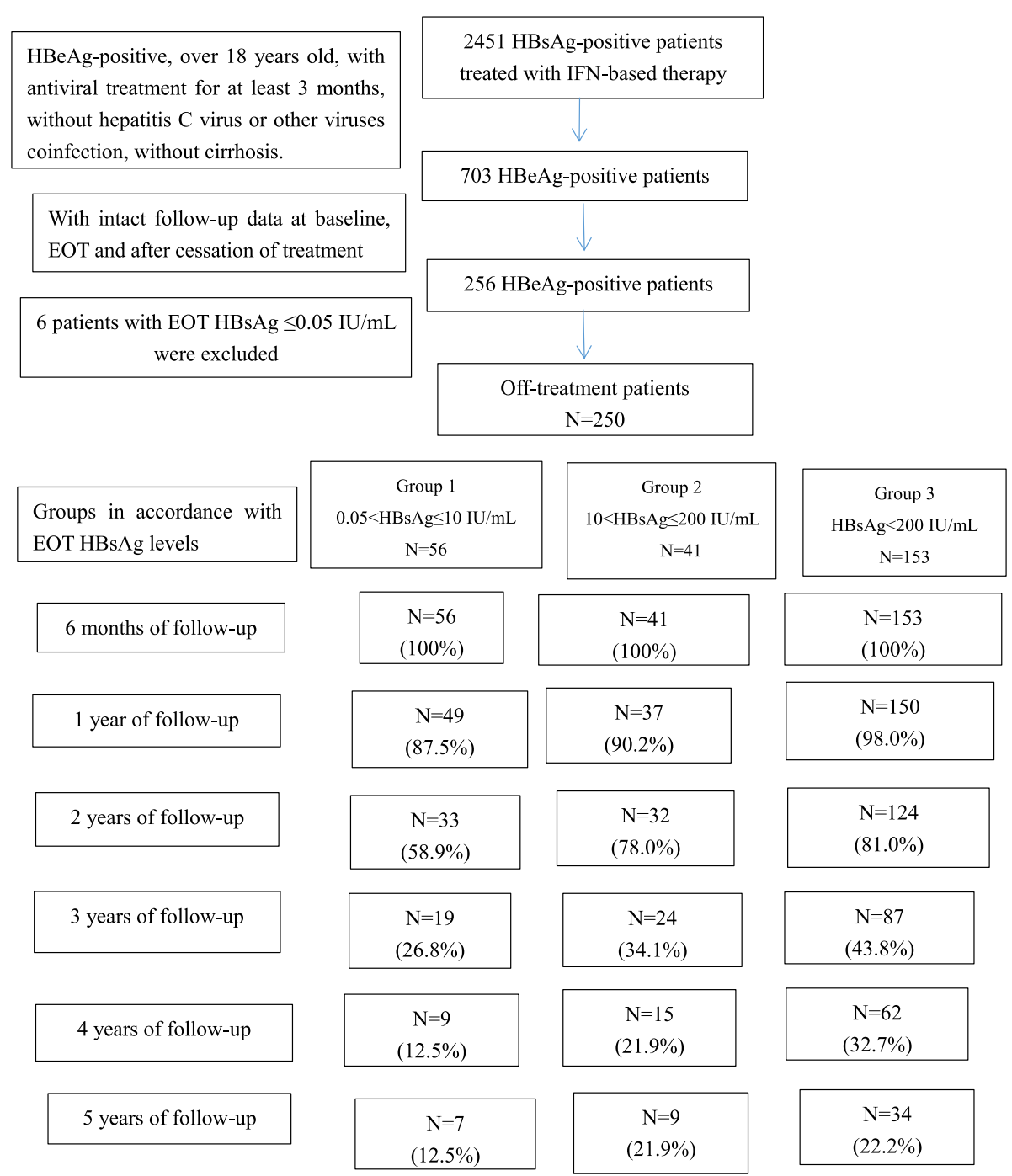

Fig. 1 Flowchart of study. IFN, interferon. EOT, end-of-treatment

gaussian distribution and skewed distribution, respectively. Intra-group differences were analyzed by t-test, when appropriate. Differences between groups were analyzed by Kruskal-Wallis $\mathrm{H}$ test and F-test, when applicable. Categorical variables were analyzed with Chisquared test and shown as numbers (rate). We performed Kaplan-Meier analysis to compare cumulative HBsAg seroclearance rates between patients with different EOT HBsAg levels and data were censored after 5 years of follow-up. Cox regression analysis was conducted to identify prognostic factors for HBsAg loss in off-treatment patients. Multivariate Logistic regression analysis was also performed to identify potential factors associated with EOT HBsAg level. All statistical analyses were carried out with IBM SPSS Statistics for Windows, V.24.0. A $p$-value $<0.05$ was taken for statistical significance.

\section{Results}

Patient characteristics

Baseline characteristics of all patients grouped according to EOT HBsAg levels were summarized in Table 1. Except for the duration of IFN and baseline HBsAg level, in the distribution of gender, age, baseline HBV DNA and ALT level, no significant differences were observed between the three subgroups.

\section{Correlation of EOT HBsAg level with post-treatment HBsAg loss}

At the EOT, the average expression of HBsAg in all patients was $2.4 \pm 1.7 \log 10 \mathrm{IU} / \mathrm{mL} .22 .4 \%$ patients had HBsAg level of $>0.05$ and $\leq 10 \mathrm{IU} / \mathrm{mL}, 16.4 \%$ had $\mathrm{HBsAg}$ level of $>10$ and $\leq 200 \mathrm{IU} / \mathrm{mL}$, and $61.2 \%$ had HBsAg level of $>200 \mathrm{IU} / \mathrm{mL}$. Kaplan-Meier analysis was conducted to evaluate the association of EOT HBsAg level 
Table 1 General characteristics of patients

\begin{tabular}{|c|c|c|c|c|}
\hline & \multirow{2}{*}{$\begin{array}{l}\text { Group } 1 \\
N=56\end{array}$} & \multirow{2}{*}{$\begin{array}{l}\text { Group } 2 \\
N=41\end{array}$} & \multirow{2}{*}{$\begin{array}{l}\text { Group } 3 \\
N=153\end{array}$} & \multirow[t]{2}{*}{$p$-value } \\
\hline & & & & \\
\hline Gender, male (\%) & $44(78.6 \%)$ & $33(80.5 \%)$ & $113(73.9 \%)$ & 0.594 \\
\hline Age (years) & $27.3 \pm 6.3$ & $29.9 \pm 8.2$ & $29.1 \pm 6.9$ & 0.147 \\
\hline Duration of IFN (months) & $15.3 \pm 5.8$ & $17.6 \pm 7.3$ & $12.0 \pm 6.0$ & $<0.001$ \\
\hline Baseline HBsAg $\left(\log _{10} \mathrm{l} / \mathrm{mL}\right)$ & $3.1 \pm 1.3$ & $3.1 \pm 1.0$ & $3.9 \pm 0.6$ & $<0.001$ \\
\hline Baseline HBV DNA $\left(\log _{10} 1 \mathrm{U} / \mathrm{mL}\right)$ & $5.7 \pm 2.2$ & $5.9 \pm 1.9$ & $6.2 \pm 1.9$ & 0.453 \\
\hline Baseline ALT (U/L) & $154.1 \pm 143.8$ & $109.1 \pm 106.9$ & $169.2 \pm 213.4$ & 0.356 \\
\hline
\end{tabular}

IFN interferon, ALT alanine aminotransferase. Continuous variables are shown as mean \pm SD, categorical variables as $\mathrm{n}(\%) . P$-values $<0.05$ are shown in bold italics

with cumulative HBsAg loss rates. After 5 years of follow-up, the patients in Group 1 exhibited significantly higher $\mathrm{HBsAg}$ loss rate of $30.4 \%$ (17/56), and in group 2 and group 3, the cumulative $\mathrm{HBsAg}$ loss rates were $9.8 \%$ $(4 / 41)$ and $0 \%(0 / 153)$, respectively $(p<0.001)$ (Fig. 2$)$. Moreover, HBsAg level of $>10 \mathrm{IU} / \mathrm{mL}$ showed relatively high negative predictive value (NPV) of up to $97.9 \%$ for HBsAg loss.

\section{Prognostic factors for post-treatment HBsAg loss}

A total of 21 patients (8.4\%) achieved post-treatment HBsAg loss. We conducted Cox regression analysis to identify prognostic factors for $\mathrm{HBsAg}$ loss in offtreatment patients. As shown in Table 2, baseline HBsAg levels of $<25,000 \mathrm{IU} / \mathrm{mL}$, on-treatment $\mathrm{HBs} A g$ decline of $>1 \log 10 \mathrm{IU} / \mathrm{mL}$ at 24 weeks of treatment and EOT $\mathrm{HBsAg}$ level of $\leq 10 \mathrm{IU} / \mathrm{mL}$ were found significantly associated with HBsAg loss and contributive to the incidence $(p<0.001, p=0.001$ and $\mathrm{p}=0.001$, respectively).

\section{Factors affecting EOT HBsAg level}

We further performed logistic regression analysis to identify patients who tend to obtain EOT HBsAg level $\leq$ $10 \mathrm{IU} / \mathrm{mL}$. As shown in Table 3, high level of baseline ALT ( $>4$ times the upper limits of normal [ULN]), low level of baseline HBV DNA $(<2 \times 106 \mathrm{IU} / \mathrm{mL})$ and low level of baseline HBsAg $(<25,000 \mathrm{IU} / \mathrm{mL})$ were significantly associated with relatively low EOT HBsAg of $\leq 10$ $\mathrm{IU} / \mathrm{mL}$, moreover, HBsAg decline $>1 \log 10 \mathrm{IU} / \mathrm{mL}$ and HBV DNA decline $>2 \log 10 \mathrm{IU} / \mathrm{mL}$ at 24 weeks of treatment exhibited consistently statistical significance.

\section{Comparison of patients with EOT HBsAg loss and in group 1}

After receiving IFN-based therapy, a total of 23 patients have achieved HBsAg loss. Among them, 6 patients have achieved HBsAg loss at EOT with a average duration of 17.3 months. Each of them has received treatment of > 12 months. 17 patients in Group 1 (HBsAg $\leq 10 \mathrm{IU} / \mathrm{mL}$ ) have achieved post-treatment HBsAg loss, 15 of them

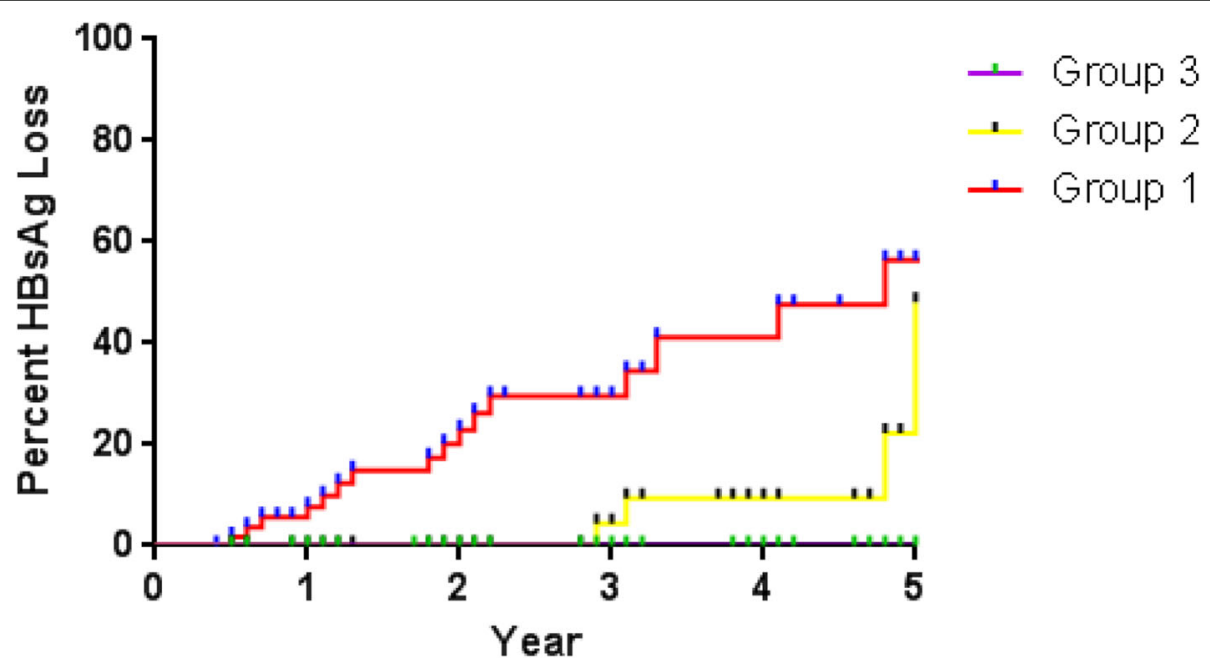

Fig. 2 Association of EOT HBsAg level with cumulative HBsAg loss rates. Kaplan Meier curves show the association of EOT HBsAg level with cumulative HBsAg loss rates. Group 1, HBsAg > 0.05 and $\leq 10 \mathrm{IU} / \mathrm{mL}$; Group 2, HBsAg $>10$ and $\leq 200 \mathrm{IU} / \mathrm{mL}$; Group 3, HBsAg > $200 \mathrm{IU} / \mathrm{mL}$. The Kaplan Meier analysis obtained a $p$-value of $<0.001$ 
Table 2 Cox regression analysis to identify prognostic factors for HBsAg loss in off-treatment patients

\begin{tabular}{llll}
\hline Variables & HR & $95 \% \mathrm{Cl}$ & $p$-value \\
\hline Male & 1.674 & $0.244-11.475$ & 0.600 \\
Over 30 years old & 0.703 & $0.095-5.183$ & 0.730 \\
Baseline $\mathrm{ALT}>4 \times \mathrm{ULN} \mathrm{U} / \mathrm{L}$ & 1.395 & $0.380-5.121$ & 0.616 \\
Baseline HBV DNA $<2 \times 10^{6} \mathrm{IU} / \mathrm{mL}$ & 0.097 & $0.007-1.379$ & $\mathbf{0 . 0 8 5}$ \\
Baseline HBsAg $<25,000 \mathrm{IU} / \mathrm{mL}$ & 7.799 & $2.903-20.947$ & $\mathbf{0 . 0 0 1}$ \\
On-treatment HBsAg decline $>1 \log _{10} \mathrm{IU} / \mathrm{mL}$ at week 24 & 8.329 & $\mathbf{2 . 4 7 0 - 2 8 . 0 8 7}$ & $\mathbf{0 . 0 0 1}$ \\
On-treatment HBV DNA decline $>2 \log _{10} \mathrm{IU} / \mathrm{mL}$ at week 24 & 12.726 & $0.627-258.244$ & 0.098 \\
Duration of IFN over 1 year & 0.253 & $0.049-1.310$ & 0.101 \\
EOT HBsAg $\leq 10 \mathrm{IU} / \mathrm{mL}$ & 7.918 & $2.453-25.556$ & $\mathbf{0 . 0 0 1}$ \\
\hline
\end{tabular}

ALT alanine aminotransferase, ULN upper limit of normal, IFN interferon, EOT end-of-treatment. $P$-values $<0.05$ are shown in bold italics

showed treatment duration of $>12$ months and the average duration of the 17 patients was 14.5 months. Baseline characteristics, dynamic changes of on-treatment HBsAg and duration of IFN therapy were balanced across patients with EOT or post-treatment HBsAg loss, shown in Table 4.

\section{Discussion}

In this retrospective observational study, we demonstrated that in $\mathrm{HBeAg}$ positive patients treated with IFN, patients with EOT HBsAg $\leq 200 \mathrm{IU} / \mathrm{mL}$, especially $\leq 10 \mathrm{IU} / \mathrm{mL}$, might achieve better post-treatment response after cessation of therapy. Among all patients, HBsAg loss at 5 years post-treatment was achieved by $21(8.4 \%)$ individuals, and 17 belonged to group 1 (30.4\%), 4 belonged to group 2 (9.7\%). HBsAg reversion was not observed during the whole follow-up. The post-treatment response to IFN observed in this study is consistent with Chuang et al. and Marcellin et al. reports [11, 16].

At present, the response rate of IFN therapy is not satisfactory. Pretreatment HBsAg, viral load and ALT levels were highlighted to predict post-treatment response of IFN therapy. For CHB patients with pretreatment high ALT level, low viral load and low HBsAg level, treatment with IFN leads to better clinical outcomes [24-27]. Consistent with previous studies, in our study, we found that baseline ALT $>4 \times \mathrm{ULN}$, HBV DNA $<2 \times 106 \mathrm{IU} / \mathrm{mL}$ and $\mathrm{HBsAg}<25,000 \mathrm{IU} / \mathrm{mL}$ were significantly associated with EOT $\mathrm{HBsAg} \leq 10 \mathrm{IU} / \mathrm{mL}$. Likewise, patients with HBsAg decline $>1 \log 10 \mathrm{IU} / \mathrm{mL}$ and HBV DNA decline $>2 \log 10 \mathrm{IU} / \mathrm{mL}$ at 24 weeks of treatment were likely to achieve HBsAg $\leq 10 \mathrm{IU} / \mathrm{mL}$ at EOT, consistent with previous reports that response-guided treatment adjustment (the RGT rule) might optimize the on-treatment and off-treatment management [16-21]. Furthermore, we demonstrated that, pretreatment low level of HBsAg, HBsAg decline $>1 \log 10 \mathrm{IU} / \mathrm{mL}$ at 24 weeks of treatment and EOT HBsAg $\leq 10 \mathrm{IU} / \mathrm{mL}$ were associated with posttreatment HBsAg loss, indicating that on-treatment response can also predict serological response of long-term follow-up after treatment cessation. We also demonstrated that EOT HBsAg level can serve as prognostic factor for post-treatment response to IFN. EOT $\mathrm{HBsAg} \leq 10 \mathrm{IU} / \mathrm{mL}$ was found to be a protective factor, and a HBsAg level > $10 \mathrm{IU} / \mathrm{mL}$ can serve as a satisfactory negative predictor for post-treatment HBsAg loss (NPV of 97.9\%). Thus, for patients with EOT HBsAg level $>10 \mathrm{IU} / \mathrm{mL}$, cessation of treatment may not be recommended. Furthermore, it has been reported that the extended IFN treatment improves the outcome of HBeAg-negative patients [28]. In a clinical trial with relatively small sample size, extending the duration of IFN to 60 weeks has been found to result in a

Table 3 Logistic regression analysis to identify potential factors associated with EOT HBsAg level $\leq 10 \mathrm{lU} / \mathrm{mL}$

\begin{tabular}{llll}
\hline Variables & $H R$ & $95 \% \mathrm{Cl}$ & $p$-value \\
\hline Male & 0.605 & $0.184-1.985$ & 0.407 \\
Over 30 years old & 0.664 & $0.179-2.458$ & 0.540 \\
Baseline ALT $>4 \times \mathrm{ULN} \mathrm{U} / \mathrm{L}$ & 17.241 & $1.689-166.667$ & $\mathbf{0 . 0 1 6}$ \\
Baseline HBV DNA $<2 \times 10^{6} \mathrm{IU} / \mathrm{mL}$ & 7.813 & $1.961-31.250$ & $\mathbf{0 . 0 0 4}$ \\
Baseline HBsAg $<25,000 \mathrm{IU} / \mathrm{mL}$ & 1.624 & $1.083-2.435$ & $\mathbf{0 . 0 1 9}$ \\
On-treatment HBsAg decline $>1 \log _{10} \mathrm{IU} / \mathrm{mL}$ at week 24 & 55.556 & $11.904-250$ & $\mathbf{0 . 0 0 1}$ \\
On-treatment HBV DNA decline $>2 \log _{10} \mathrm{IU} / \mathrm{mL}$ at week 24 & 14.084 & $3.003-66.667$ & $\mathbf{0 . 0 0 1}$ \\
Duration of IFN over 1 year & 2.140 & $0.680-6.736$ & 0.193 \\
\hline
\end{tabular}

ALT alanine aminotransferase, ULN upper limit of normal, IFN interferon. $P$-values $<0.05$ are shown in bold italics 
Table 4 Comparison of patients with HBsAg loss at EOT and in Group 1

\begin{tabular}{llll}
\hline Variables & EOT HBsAg loss group & HBsAg loss in Group 1 & $p$-value \\
\hline Gender, male $(\%)$ & $5(83.3 \%)$ & $12(70.6 \%)$ & 0.541 \\
Age (years) & $24.8 \pm 2.7$ & $26.5 \pm 5.7$ & 0.496 \\
Baseline ALT $(\mathrm{U} / \mathrm{L})$ & $249.8 \pm 214.0$ & $133.6 \pm 130.1$ & 0.127 \\
Baseline HBV DNA $\left(\log _{10} \mathrm{l} \mathrm{U} / \mathrm{mL}\right)$ & $4.3 \pm 1.5$ & $5.8 \pm 2.1$ & 0.133 \\
Baseline HBsAg $\left(\log _{10} \mathrm{l} / \mathrm{U} / \mathrm{mL}\right)$ & $2.6 \pm 0.9$ & $2.9 \pm 0.6$ & 0.399 \\
On-treatment HBsAg decline at week $24\left(\log _{10} \mid \mathrm{U} / \mathrm{mL}\right)$ & $1.6 \pm 1.4$ & $1.2 \pm 0.8$ & 0.37 \\
On-treatment HBV DNA decline at week $24\left(\log _{10} \mathrm{l} \mathrm{U} / \mathrm{mL}\right)$ & $1.9 \pm 1.6$ & $3.7 \pm 1.6$ & $\mathbf{0 . 0 4 1}$ \\
Duration of IFN (months) & $17.3 \pm 4.9$ & $14.5 \pm 5.2$ & 0.254 \\
\hline
\end{tabular}

$P$-value $<0.05$ is shown in bold italics

higher rate of sustained virological response, and 5 of the total 13 patients showed a $>90 \%$ decrease in HBsAg concentration after 60-week IFN treatment [29]. The consensus on pegylated interferon (Peg-IFN) reported that for the patients with undetectable HBV DNA and low HBsAg level $(<10 \mathrm{IU} / \mathrm{mL})$ at 48 weeks of Peg-IFN treatment, extended treatment to 72 weeks or even longer should be considered to achieve ideal treatment endpoint, HBsAg clearance [14]. However, the treatment gap between low HBsAg level $(\leq 10 \mathrm{IU} / \mathrm{mL})$ and $\mathrm{HBsAg}$ loss, also known as functional cure, is volatile and rather long for some of the patients. Extending the Peg-IFN treatment to 72 or 96 weeks, can not guarantee HBsAg loss for the majority of CHB patients. In this study, there were $30.4 \%$ patients who have achieved HBsAg loss in Group 1, and none of them exhibited HBsAg reversion during the whole followup. In addition, we demonstrated that the duration of IFN therapy was not associated with low EOT HBsAg level $(\leq 10 \mathrm{IU} / \mathrm{mL})$ and post-treatment HBsAg loss. Hence, offtreatment follow-up could be considered for patients achieving $\mathrm{HBsAg}$ level $\leq 10 \mathrm{IU} / \mathrm{mL}$ with inadequate economic conditions and unwillingness to extend treatment. While in Group 2, only 9.7\% patients achieved HBsAg loss. Thus, for patients with HBsAg level of $>10$ and $\leq$ $200 \mathrm{IU} / \mathrm{mL}$ at EOT of IFN, extended treatment to achieve $\mathrm{HBsAg}$ decline to $\leq 10 \mathrm{IU} / \mathrm{mL}$ is necessary before offtreatment follow-up.

We further analyzed clinical characteristics of the 17 patients who obtained EOT HBsAg $\leq 10 \mathrm{IU} / \mathrm{mL}$ and achieved post-treatment HBsAg loss. And we found that the distribution of baseline characteristics, dynamic changes of on-treatment HBsAg and duration of IFN therapy were balanced across patients with EOT or post-treatment HBsAg loss, indicating that EOT HBsAg $\leq 10 \mathrm{IU} / \mathrm{mL}$ can serve as satisfactory end-point of treatment. Recent researches concerning off-treatment HBsAg loss to NUCs therapy, have reported that both EOT HBsAg level $<200 \mathrm{IU} / \mathrm{mL}[30,31]$ and $<10 \mathrm{IU} / \mathrm{mL}$ [32] are important contributing factors in achieving offtreatment HBsAg loss. However, these studies mainly refer to virological and clinical relapse, whether $\mathrm{HBsAg}$ reversion occurred during follow-up is not mentioned. In this study, patients in Group 1 who achieved posttreatment HBsAg loss did not exhibit HBsAg reversion. The possible explanation is that IFN can suppress covalently closed circular DNA (cccDNA) in hepatocytes and modulate host immune response, the indirect antiviral effects of IFN lead to sustained immune control after treatment discontinuation $[9,10]$.

There were notable limitations to this study. First, since the retrospective design nature of our study, some indicators, including HBV genotype, HBeAg titer, liver fibrosis stage, treatment experience with prior IFN or NUCs, will inevitably be missing, and this study is biased to a certain extent. However, we enrolled a large sample of patients to minimize this limitation and should be valuable to other investigators and clinicians. Second, our study included HBeAg-positive patients only and the results were not applied for $\mathrm{HBeAg}$-negtive patitents. As we know, immune status in HBeAg-positvie is entirely different to HBeAg-negative patients which need further research. Third, HBsAg levels of treatment week 12 was not available in our study due to the incomplete data.

\section{Conclusions}

In conclusion, besides baseline HBsAg level and ontreatment dynamic changes of HBsAg level, we identified EOT HBsAg level as a monitoring indicator for IFN therapy. EOT HBsAg level of $\leq 10 \mathrm{IU} / \mathrm{mL}$ was found to lead to high rate of off-treatment HBsAg loss. For patients without willingness to extend IFN treatment, offtreatment follow-up could be considered when $\mathrm{HBsAg}$ level decreased to $\leq 10 \mathrm{IU} / \mathrm{mL}$.

\footnotetext{
Abbreviations

CHB: Chronic hepatitis B; IFN: Interferon; HBsAg: Hepatitis B surface antigen; EOT: End-of-treatment; NPV: Negative predictive value; HBV: Hepatitis B virus; HCC: Hepatocellular carcinoma; NUCs: Nucleos(t) ide analogues;

HBeAg: Hepatitis B e antigen; ALT: Alanine aminotransferase; SD: Standard deviation; ULN: Upper limits of normal; cccDNA: Covalently closed circular DNA
}

\section{Acknowledgments}

The authors thank Xiaozheng Ma, Juanjun Liao for collecting clinical data for this study. 


\section{Authors' contributions}

Study conception and design: JP and SW. Acquisition, analysis and/or interpretation of data: SW and WFL. Drafting/revision of the work for intellectual content and context: SW, WFL, YW, and HJC. Final approval and overall responsibility for the published work: JP. All of the authors read and approved the final manuscript.

\section{Funding}

This work was supported by the grants from the Major Science and Technology Special Project of China (2017ZX09304016,

2017ZX10302201004008),

\section{Availability of data and materials}

The datasets used and/or analysed during the current study are available from the corresponding author upon reasonable request.

\section{Ethics approval and consent to participate}

The study was approved by the clinical research ethics committee of Nanfang Hospital of Southern Medical University. Written informed consent was obtained by all of the participants.

\section{Consent for publication}

Not applicable.

\section{Competing interests}

The authors declare that they have no competing interests.

Received: 28 June 2019 Accepted: 5 April 2020

Published online: 21 April 2020

\section{References}

1. Schweitzer A, Horn J, Mikolajczyk RT, Krause G, Ott JJ. Estimations of worldwide prevalence of chronic hepatitis B virus infection: a systematic review of data published between 1965 and 2013. Lancet. 2015;386(10003):1546-55.

2. Wang FS, Fan JG, Zhang Z, Gao B, Wang HY. The global burden of liver disease: the major impact of China. HEPATOLOGY. 2014;60(6):2099-108.

3. Iloeje UH, Yang HI, Su J, Jen CL, You SL, Chen Cl. Predicting cirrhosis risk based on the level of circulating hepatitis B viral load. Gastroenterol. 2006;130(3):678-86.

4. Chang TT, Liaw YF, Wu SS, Schiff E, Han KH, Lai CL, Safadi R, Lee SS, Halota W, Goodman Z, et al. Long-term entecavir therapy results in the reversal of fibrosis/cirrhosis and continued histological improvement in patients with chronic hepatitis B. Hepatol. 2010;52(3):886-93.

5. Zoutendijk R, Reijnders JG, Zoulim F, Brown A, Mutimer DJ, Deterding K, Hofmann WP, Petersen J, Fasano M, Buti M, et al. Virological response to entecavir is associated with a better clinical outcome in chronic hepatitis B patients with cirrhosis. Gut. 2013;62(5):760-5.

6. van Zonneveld M, Honkoop P, Hansen BE, Niesters HGM, Murad SD, de Man RA, Schalm SW, Janssen HLA. Long-term follow-up of alpha-interferon treatment of patients with chronic hepatitis B. Hepatol. 2004:39(3):804-10.

7. Lin SM, Yu ML, Lee CM, Chien RN, Sheen IS, Chu CM, Liaw YF. Interferon therapy in $\mathrm{HBeAg}$ positive chronic hepatitis reduces progression to cirrhosis and hepatocellular carcinoma. J Hepatol. 2007;46(1):45-52.

8. Zheng Z, Liao W, Liu L, Cai S, Zhu H, Yin S. Effect of nucleos(t) ide analogue on serum HBsAg level in chronic hepatitis B patients: a 3-years study. Biomed Pharmacother. 2020;122:109698.

9. Liaw YF, Kao JH, Piratvisuth T, Chan HL, Chien RN, Liu CJ, Gane E, Locarnini S, Lim SG, Han KH, et al. Asian-Pacific consensus statement on the management of chronic hepatitis B: a 2012 update. Hepatol Int. 2012;6(3):531-61.

10. European Association For The Study Of The Liver. EASL clinical practice guidelines: Management of chronic hepatitis B virus infection. J Hepatol. 2012;57(1):167-185.

11. Chuang WL, Jia J, Chan HLY, Han KH, Tanwandee T, Tan D, Chen X, Gane E, Piratvisuth $\mathrm{T}$, Chen $\mathrm{L}$, et al. Responses are durable for up to 5 years after completion of peginterferon alfa-2a treatment in hepatitis B e antigenpositive patients. Aliment Pharm Ther. 2018;47(9):1306-16.

12. Li SY, Li H, Xiong YL, Liu F, Peng ML, Zhang DZ, Ren H, Hu P. Peginterferon is preferable to entecavir for prevention of unfavourable events in patients with HBeAg-positive chronic hepatitis B: a five-year observational cohort study. J Viral Hepatitis. 2017;24:12-20.

13. Lau G, Piratvisuth T, Luo KX, Marcellin P, Thongsawat S, Cooksley G, Gane E, Fried MW, Popescu M, Wu J. Durability of response and occurrence of late response to peginterferon alpha-2a (40KD)[PEGASYS] one year post- treatment in patients with HBeAg-positive chronic hepatitis B. J Hepatol. 2006:44:S23-4.

14. Wenhong Z, Dazhi Z, Xiaoguang D, Qing X, Jiaji J, Xinyue C. Consensus on pegylated interferon alpha in treatment of chronic hepatitis B. Chin J Hepatol. 2017;9:678-86.

15. Lampertico P, Agarwal K, Berg T, Buti M, Janssen HLA, Papatheodoridis G, Zoulim F, Tacke F. EASL 2017 clinical practice guidelines on the management of hepatitis B virus infection. J Hepatol. 2017;67(2):370-98.

16. Marcellin P, Bonino F, Yurdaydin C, Hadziyannis S, Moucari R, Kapprell HP, Rothe V, Popescu M, Brunetto MR. Hepatitis B surface antigen levels: association with 5-year response to peginterferon alfa-2a in hepatitis B eantigen-negative patients. Hepatol Int. 2013;7(1):88-97.

17. Moucari R, Mackiewicz V, Lada O, Ripault M, Castelnau C, Martinot-Peignoux M, Dauvergne A, Asselah T, Boyer N, Bedossa P, et al. Early serum HBsAg drop: a strong predictor of sustained virological response to pegylated interferon alfa2a in HBeAg-negative patients. Hepatology. 2009;49(4):1151-7.

18. Sonneveld MJ, Hansen BE, Piratvisuth T, Jia JD, Zeuzem S, Gane E, Liaw YF Xie Q, Heathcote EJ, Chan HLY, et al. Response-guided peginterferon therapy in hepatitis B e antigen-positive chronic hepatitis B using serum hepatitis B surface antigen levels. Hepatology. 2013;58(3):872-80.

19. Piratvisuth T, Marcellin P, Popescu M, Kapprell H, Rothe V, Lu Z. Hepatitis B surface antigen: association with sustained response to peginterferon alfa$2 a$ in hepatitis B e antigen-positive patients. Hepatol Int. 2013;7(2):429-36.

20. Sun J, Ma H, Xie Q, Xie Y, Sun Y, Wang H, Shi G, Wan M, Niu J, Ning Q, et al. Response-guided peginterferon therapy in patients with HBeAg-positive chronic hepatitis B: a randomized controlled study. J Hepatol. 2016;65(4):674-82.

21. Chen G. Baseline HBsAg predicts response to pegylated interferon- $\mathrm{a} 2 \mathrm{~b}$ in HBeAgpositive chronic hepatitis B patients. World J Gastroenterol. 2014;20(25):8195.

22. Brunetto MR, Moriconi F, Bonino F, Lau GKK, Farci P, Yurdaydin C, Piratvisuth T, Luo K, Wang Y, Hadziyannis S, et al. Hepatitis B virus surface antigen levels: a guide to sustained response to peginterferon alfa-2a in $\mathrm{HBeAg}$ negative chronic hepatitis B. Hepatology. 2009;49(4):1141-50.

23. Ning Q, Han M, Sun Y, Jiang J, Tan D, Hou J, Tang H, Sheng J, Zhao M. Switching from entecavir to PegIFN alfa-2a in patients with HBeAg-positive chronic hepatitis B: a randomised open-label trial (OSST trial). J Hepatol. 2014;61(4):777-84

24. Buster EHCJ, Hansen BE, Lau GKK, Piratvisuth T, Zeuzem S, Steyerberg EW, Janssen HLA. Factors that predict response of patients with hepatitis B e antigen-positive chronic hepatitis B to Peginterferon-Alfa. Gastroenterology. 2009;137(6):2002-9.

25. Wang Y, Yang S, Su C, Wang Y, Lee K, Huo T, Lin H, Huang Y. Predictors of response to pegylated interferon in chronic hepatitis $\mathrm{B}$ : a real-world hospital-based analysis. Sci Rep-UK. 2016;6(1):29605.

26. Xue X, Cai S. Comment on "assessment of liver stiffness in pediatric Fontan patients using transient Elastography". Can J Gastroenterol Hepatol. 2016;2016:9343960.

27. Zheng C, Yan H, Zeng J, Cai S, Wu X. Comparison of pegylated interferon monotherapy and de novo pegylated interferon plus tenofovir combination therapy in patients with chronic hepatitis B. Infect Drug Resist. 2019;12:845-54.

28. Lampertico P, Del Ninno E, Viganò M, Romeo R, Donato MF, Sablon E, Morabito A, Colombo M. Long-term suppression of hepatitis B e antigen-negative chronic hepatitis B by 24-month interferon therapy. Hepatology. 2003;37(4):756-63.

29. Gish RG, Lau DT, Schmid P, Perrillo R. A pilot study of extended duration peginterferon alfa-2a for patients with hepatitis B e antigen-negative chronic hepatitis B. Am J Gastroenterol. 2007;102(12):2718-23.

30. Yao C, Hung C, Hu T, Lu S, Wang J, Lee C, Chen C. Incidence and predictors of $\mathrm{HBV}$ relapse after cessation of nucleoside analogues in HBeAg-negative patients with HBsAg $\leq 200 \mathrm{IU} / \mathrm{mL}$. Sci Rep-UK. 2017;7(1):1839.

31. Cao J, Chi H, Yu T, Li Z, Hansen BE, Zhang X, Zhong C, Sun J, Hou J, Janssen HLA, et al. Off-treatment hepatitis B virus (HBV) DNA levels and the prediction of relapse after discontinuation of Nucleos(t) ide analogue therapy in patients with chronic hepatitis B: a prospective stop study. J Infect Dis. 2017;215(4):581-9.

32. Hsu YC, Mo LR, Chang CY, Wu MS, Kao JH, Wang WL, Yang TH, Wang CS, Chiang MF, Chen CC, et al. Association between serum level of hepatitis B surface antigen at end of Entecavir therapy and risk of relapse in $E$ antigennegative patients. Clin Gastroenterol Hepatol. 2016;14(10):1490-8.

\section{Publisher's Note}

Springer Nature remains neutral with regard to jurisdictional claims in published maps and institutional affiliations. 